\title{
Car Sharing in Poland - The Perspective of Operators and Cities in the First Comparative Research Study ${ }^{1}$
}

\author{
Grzegorz Tchorek*, Filip Targowski**, Pawet Krzewicki***, \\ Waldemar Koziot*****, Stefan Wójtowicz ${ }^{* * * * * *}$
}

The main goal of the paper is to assess the awareness and understanding of the so-called shared mobility among the representatives of car sharing operators and cities in one of the first studies on this issue undertaken in Poland. We asked two groups of stakeholders in Polandcar sharing operators (7 companies) and cities (19 entities) - about the current state and the future of shared mobility. Research was conducted using web questionnaires between January and April 2018. The main observations are as follows.

Firstly, public transport is one of the main areas determining citizens' quality of life, and Polish cities seem to realize it. While the Smart City concept and smart mobility are at an early stage of development, city authorities search for optimal solutions increasing the quality of public transport, including experimentation with shared mobility and car sharing.

Secondly, the car sharing market in Poland is relatively young and, taking into consideration data from more developed car sharing markets (e.g. Germany), we can expect that it will grow rapidly in the next years. Many entities from different backgrounds (energy companies, car rental companies, municipal authorities) are entering the Polish shared mobility market. Thirdly, the critical factors which will be decisive for the future development of the car sharing market are: a) close cooperation between cities and operators to make different forms of shared mobility and their accessibility more complementary, $b$ ) availability of parking spaces dedicated to car sharing services.

Keywords: shared mobility, car sharing, electromobility, smart city, sharing economy.

Submitted: 07.06.18 | Accepted: 13.09.18

\section{Carsharing w Polsce - perspektywa operatorów i miast w pierwszym badaniu porównawczym}

Gtównym celem artykułu jest ocena świadomości i zrozumienia idei tzw. mobilności wspótdzielonej wśród przedstawicieli operatorów carsharingu i miast $w$ jednym z pierwszych badań

\footnotetext{
* Grzegorz Tchorek - dr, Faculty of Management, University of Warsaw. https://orcid.org/0000-00030307-7639.

** Filip Targowski - mgr, Faculty of Management, University of Warsaw.

*** Paweł Krzewicki - mgr, Faculty of Management, University of Warsaw.

**** Waldemar Koziol - dr, Faculty of Management, University of Warsaw. https://orcid.org/0000-00017812-9355.

****** Stefan Wójtowicz - mgr, Faculty of Management, University of Warsaw.

Correspondence address: Faculty of Management, University of Warsaw, ul. Szturmowa 1/3, 02-678 Warszawa; e-mail: gtchorek@wz.uw.edu.pl.
} 
w Polsce. Zapytaliśmy dwie grupy interesariuszy - operatorów carsharingu (7 firm) i przedstawicieli miast (19 podmiotów) - o obecny stan i przysztość mobilności wspótdzielonej. Badania ankietowe przeprowadzono za pomoca kwestionariuszy internetowych między styczniem a kwietniem 2018 r. Gtówne obserwacje sa następujace. Po pierwsze, transport publiczny jest jednym z podstawowych obszarów decydujacych o jakości życia obywateli, a polskie miasta zdają sobie z tego sprawę. Podczas gdy koncepcja Smart City i inteligentna mobilność sa na wczesnym etapie rozwoju, wtadze miasta szukaja optymalnych rozwiazań podnoszacych jakość transportu publicznego, w tym eksperymentują z mobilnościa wspótdzielona i carsharingiem. Po drugie, rynek carsharingu w Polsce jest stosunkowo mtody, a biorac pod uwage dane z bardziej rozwiniętych rynków (np. z Niemiec), możemy spodziewać się szybkiego jego wzrostu w kolejnych latach. Wiele podmiotów z różnych środowisk (firmy energetyczne, wypożyczalnie samochodów, władze miejskie) wkracza na rynek mobilności wspótdzielonej. Po trzecie, kluczowymi czynnikami decydujacymi o przyszlym rozwoju rynku carsharingu będą: a) ścista wspótpraca między miastami i operatorami w celu uzupetnienia różnych form wspólnej mobilności i zapewnienia ich dostępności; b) dostępność miejsc parkingowych przeznaczonych dla samochodów wspótdzielonych.

Słowa kluczowe: mobilność współdzielona, carsharing, elektromobilność, inteligentne miasto, ekonomia współdzielenia.

Nadesłany: 07.06.18 | Zaakceptowany do druku: 13.09.18

JEL: D1, R40, R50, Q50

\section{Introduction}

The inspiration for our research interest is provided by the increase in environmental pollution in large cities and the resulting higher mortality rates (Jerrett et al., 2013). Along with technological changes, urbanization and concentration of population in large agglomerations are taking place. In 2015 , almost $75 \%$ of the EU population lived in urban areas and it is expected to reach $85 \%$ globally within the next two to three decades.

In addition, the existing model of car use seems to be inefficient from the point of view of resource allocation and urban logistics. For over $95 \%$ of its life cycle, a (private) vehicle is not used but only occupies space. According to a report produced by the RAC Foundation on the basis of the UK Department for Transport database, a typical private passenger car is driven for six hours a week and parked for the remaining 162 hours (Bates \& Leibling, 2012). Thus, an average car is only used for $3.5 \%$ of the lifetime, and the remaining $96.5 \%$ is spent in a car park $(80 \%$ at home, $16.5 \%$ off the owner's home). These problems are becoming more and more acute, so European governments are paying more attention by seeking solutions such as car sharing and electromobility, combining them with the sustainable development idea (Tchorek et al., 2018).

Shared mobility and car sharing, in their roots and approach, can be treated as an important element of how cities respond to congestion and smog problems (Katzev, 2003). Car sharing is a service in which different types of engines can be used - combustion, hybrid, gas and electric, although the traditional combustion one is the most flexible in terms of accessibility. Nevertheless, even if car sharing uses "traditional" engines, its contribution to reducing congestion and pollution can be positive. That is why shared mobility is the subject of our concerns. Additionally, it is also very interesting what is the outlook for car sharing business in the very young Polish market, where this activity started to operate just in 2017.

There is a growing need to recognize challenges faced by shared mobility operators and their critical role in creating shared mobility ecosystems. The second important stakeholder group includes local governments and authorities influencing local mobility systems.

Considering all the above, the main goal of the article is to assess the awareness and understanding of the shared mobility role in Polish cities and an in-depth analysis of the development of car sharing services in Poland. 


\section{Research Methodology}

The following paper summarizes the results of two studies, conducted in Poland at the beginning of 2018, that related to the understanding of shared mobility by cities and car sharing operators.

The first study focuses on the concept of Smart City. Data were collected through an online questionnaire in March and April 2018 at the Faculty of Management, University of Warsaw, as part of a research project carried out for Electromobility Poland. Nineteen municipalities filled in the questionnaire: Bytom, CzechowiceDziedzice, Częstochowa, Gdynia, Gmina Miasta Wejherowa, Gmina Miasto Ełk, Gmina Miejska Głogów, Gmina Miejska Kraków, Gmina Olsztyn, Gmina Pasłęk, Grodzisk Wielkopolski, Kozienice, Mińsk Mazowiecki, Poznań, Siemianowice Śląskie, Sopot, Tychy, Wołomin, Września.

The aim of the research was to recognize the attitude towards and the potential for the implementation of the Smart City concept and smart mobility, including areas of shared mobility and low-emission vehicles, in Polish municipalities. The respondents answered 18 questions some of which corresponded directly to the research conducted on car sharing operators.

The second study focused on car sharing operators. Data were collected through an online questionnaire in January 2018 at the Faculty of Management, University of Warsaw. Twenty-six questionnaire questions were answered by six companies which represented almost the whole car sharing market in Poland in 2017 (only one company did not fill in the questionnaire). The companies which operated in Poland at that time were: Traficar, Panek CarSharing, 4mobility, Enigma (Vozilla), Keratronik, POL-MOT Auto S.A. (Omni) and Enspirion.

Our study on the assessment of shared mobility stakeholders in Poland involved a number of data collection methods, both qualitative and quantitative. Online questionnaires and data collected thereby were deliberated on during discussion panels and in-depth interviews with market experts. The online questionnaire was chosen as a complementary data collection method for discussion panels and interviews. The link to the questionnaire concerning the concept of Smart City was distributed to contacts included in the mailing list database of the Association of Polish Cities (Związek Miast Polskich). Contacts to car sharing operators were collected from their official websites and discussion panels.

In the paper, we also compare Poland and Germany to show differences between the developed German car sharing market and the young, undeveloped Polish one. The comparison not only shows an early stage of development of car sharing in Poland but also a possible direction of its evolution. Furthermore, companies in both countries operate in similar weather conditions, which is an important factor for mobility usage within cities, and customers might share similar behaviour patterns in many aspects.

\section{Shared Mobility as Part of the Smart (City) Mobility Phenomenon}

Contemporary cities continue developing and are becoming complex systems whose functioning affects the quality of life of their inhabitants (Caragliu, Del Bo, \& Nijkamp, 2011). It is especially essential in the context of mechanization and automatization of agriculture and industry, which contributes to the migration from rural to urban areas. Figure 1 shows changes in the share of urban dwellers in the whole population between 1990 and 2015 and a prediction of changes in the following years. United Nations data shows that a vast majority of world population has lived in urban regions since 2010; moreover, a further dynamic growth of this indicator is predicted.

The increase in environmental pollution, as one of the main causes of exacerbating health problems including pulmonary disease, is a particularly meaningful issue (Sunyer, 2001). The solution, the same as the answer to transformations in different socio-economic spheres including demography, culture and environment, requires a new approach taking into account previous technological progress. It is especially apparent in engineering or economic literature, additionally in areas of goal adoption or political strategies. The Smart City concept fits in the range of mentioned considerations. It concerns introducing intelligent solutions and improving the comfort of residents. 
Figure 1. Percentage of population living in urban areas, 1990-2050 (forecast)

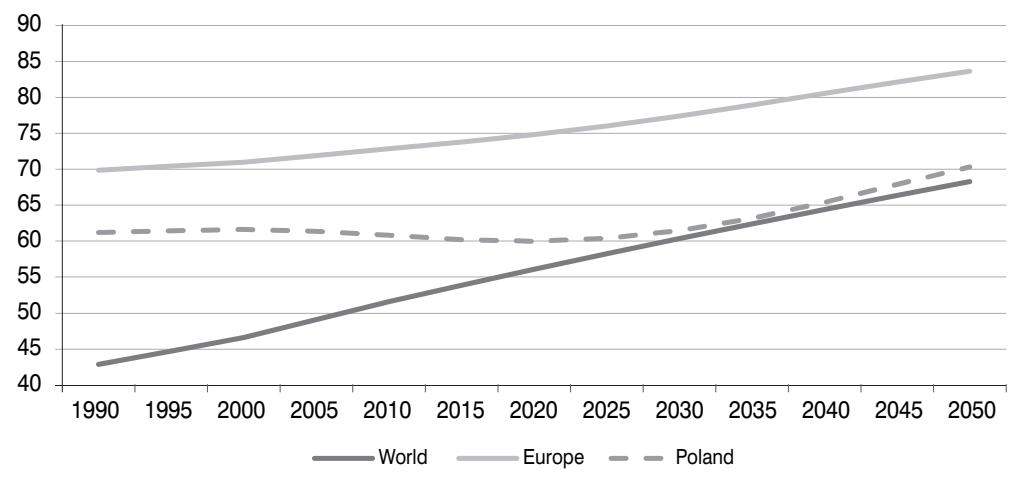

Source: UN database.

The literature on this subject does not seem to have one general definition of a Smart City. Attention mostly focuses on the aspects connected with ICT infrastructure (Roller \& Waverman, 2001). A different view, represented by the EU and OECD, takes into account the significance of education and the level of human capital. Glaeser and Berry (2006) point out that the biggest development can be observed in cities which have educated labour resources. The authors think, invoking the definition proposed by Caragliu, Del Bo and Nijkamp (2011), that a city is intelligent when investments in human capital and ICT infrastructure contribute to sustainability.

The definition of a Smart City adopted by the authors enables identifying the areas of city development, including environment, transport, society, standard of living, economy and administration. They all represent economic development based on knowledge and concentrate on economic policy activities, including the support for enterprise innovations. It is also reflected in the Polish economy.

\subsection{Smart City and Shared Mobility Concept in Polish Cities}

Strategies adopted at the central level, just like operational programmes, affect the functioning of cities, their development and innovation rate. At the same time, this process is incredibly diverse, and it is worth drawing attention to the aspects which are significant from a local perspective. The results of the survey carried out by the authors on a group of 19 cities and communes allow for identifying city development areas which are consistent with the Smart City concept. This analysis is unique compared to previous research and has a cognitive value, but, what is more, it has become an important aspect of sharing economy development, including car sharing as a future direction.

Figure 2. Smart city dimensions

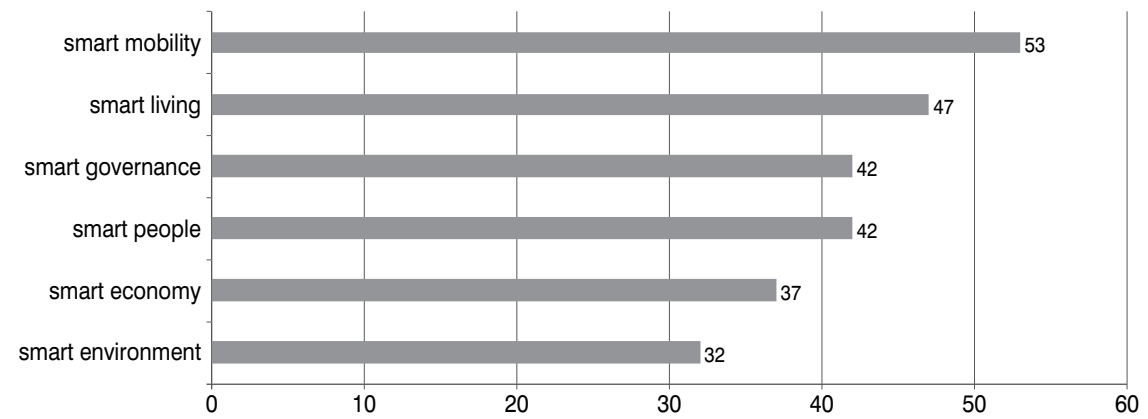

Source: Own survey among cities and communes (19 entities). 
The obtained results indicate that Polish communes and cities are interested in improving the quality of inhabitants' life. Despite a relatively early stage of ICT infrastructure implementation (in comparison to western countries), attempts at introducing the Smart City concept are visible. The most developed area is transport and ICT, with a $53 \%$ share. It is an essential element of innovation development connected with smart mobility (also car sharing). It is worth noticing that the activities in the area of sharing economy are dependent on the standard of living and the measure of progress. In the interviewees' opinion, both of these areas were developed within local governments' activities.

\subsection{Shared Mobility in Cities and Communes}

Over the years, interest in sharing economy has been increasing rapidly in both academic and business environments. Car sharing, as mentioned, is one of the forms of sharing economy developing on the basis of shared usage of vehicles provided by a company. It is a more and more common idea as we observe an increase in competitiveness and geographical diversification as well as a bigger number of vehicles operating in this business model. It also represents an essential addition to the market offer where taxi corporations or international companies like Uber or Taxify (Bolt) are natural competitors.

Polish cities exhibit a high level of awareness and responsibility, favouring in the first place the activities related to the development of public transport and tradi- tional urban cycling, followed by traditional and electric car sharing.

Figure 3 shows that an overwhelming majority (nearly 90\%) of cities and communes have plans to support the development of public transport and city bike systems. The results demonstrate that about $32 \%$ of the respondents see car sharing as an important form of sharing economy, meaning the Smart City concept as well, which at the same time requires development. Simultaneously, a vast majority of the respondents link the development in this area with electric vehicles. As regards electromobility, cities and communes much less frequently indicate the need for supporting such initiatives as electric bicycles or scooters. Here, referring to the LongTerm National Development Strategy, we should notice that a considerable number of activities for supporting low-carbon economy concentrate on public transport. This need is approved by about $90 \%$ of cities and communes taking part in the research.

The development of transport and ITC within the Smart City concept concentrates mostly on public transport, which is one of the main parts of the Electromobility Development Programme and E-Bus Programme. Therefore, car sharing can rely on limited support from both the central government and local governments. Nevertheless, it is worth noticing that this area and its potential were identified by the respondents, of whom $1 / 3$ declare pursuing an active policy in this respect. At the same time, car sharing is not perceived as an opponent of public transport, but as its

Figure 3. Direction of development of sharing economy in cities and communes

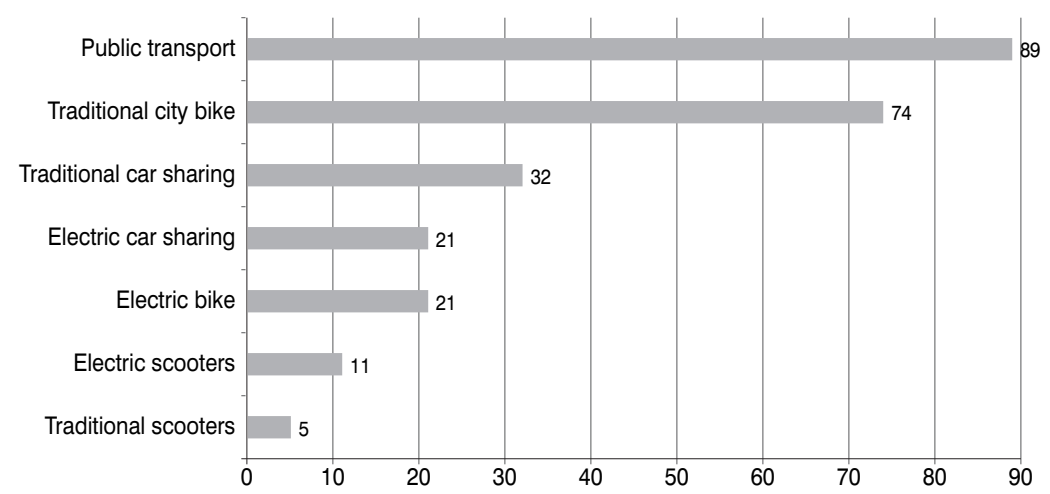

Source: Own survey among cities and communes (19 entities).

Wydział Zarządzania UW https://doi.org/10.7172/1733-9758.2018.29.5 
Figure 4. Factors determining the development of car sharing in cities and communes

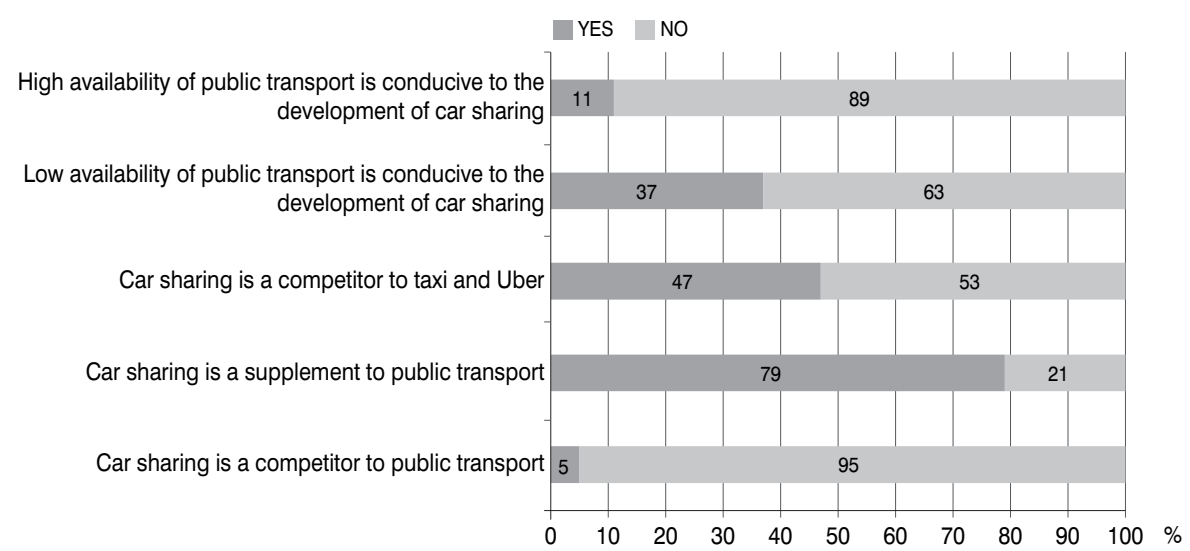

Source: Own survey among cities and communes (19 entities).

complement - Figure 4. The quality and availability of public transport also matters as it determines a potential consumer group for this market offer. Nonetheless, the mentioned factors are not major determinants because of the competition between taxi corporations like Uber but mostly because of freedom to use personal cars.

\subsection{Support Instruments for the}

\section{Development of Shared Mobility}

Research results also show that a substantial majority (about $84 \%$ ) of the respondents support the development of electromobility or activities connected with education related to shared mobility as reasonable, referring to the accepted innovative policy (see Figure 6). The authors asses that these activities are an essential, although insufficient, instrument of support. Because of that, different instruments should accompany the information policy, for example providing parking spots dedicated to car sharing (53\%), partial or total fee exemptions (37\%) or creating lowemission zones (42\%). Considering these aspects may contribute to the improvement of activities related to electromobility or the Smart City, but it will also measurably contribute to improving the quality of life of the local community.

\section{Shared Mobility and Car Sharing Phenomenon}

Shared mobility forms can be considered in the context of sharing economy (Heinrichs, 2013). A literature review indicates that the multi-threaded and interdiscipli-

Figure 5. Support instruments for sharing economy proposed by cities and communes

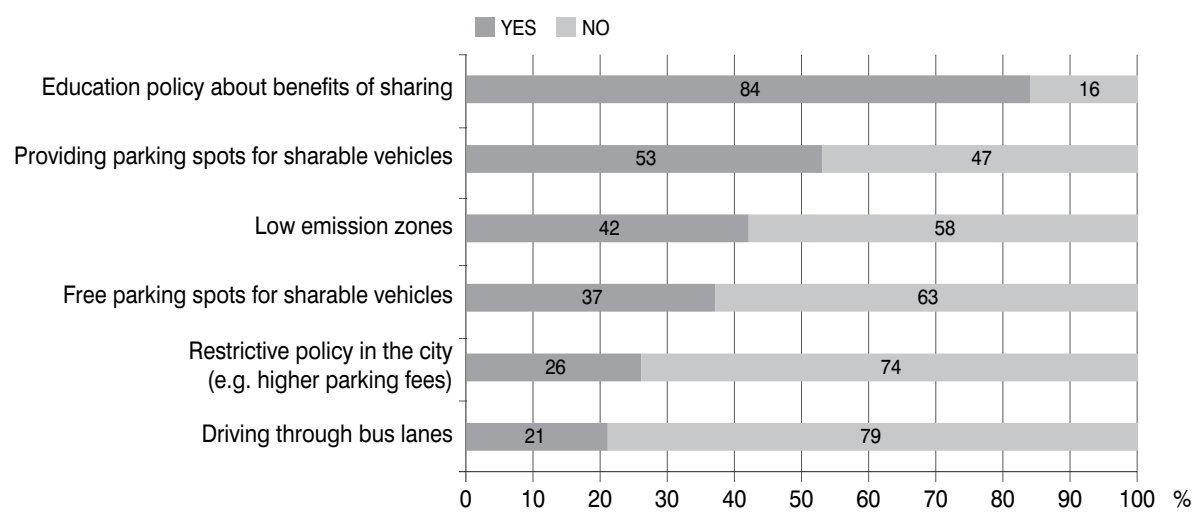

Source: Own survey among cities and communes (19 entities). 
nary approach to shared mobility is justified by the complex nature of the terms used to describe sharing economy. Collaborative consumption, co-creation of value (coproduction), and prosumption (prosumerism) constitute a set of categories that are largely related to sharing economy, also referred to as cooperation economics and access economics (Belk, 2014; Wang \& Zhang, 2012; Pollak, 1970; Ranjar \& Read, 2014). The process of sharing results from changes in the dissemination and development of ICT techniques, growing consumer awareness, changed preferences ("to be instead of have", "generation Y" and "generation Z"), commercial use of social media and economic benefits (Wang \& Zhang, 2012; Hamari et al., 2016).

Research shows that a shared vehicle can replace about 10 (some research, e.g. describing German experience confirm about 20) private cars (Shaheen et al. 2012; Münzel, 2017; Nijland \& van Meerkerk, 2017). In addition, regular use of car sharing makes some customers decide to sell the private car, and some refrain from buying one. Car sharing customers are more likely to use other forms of shared mobility and generally have more pro-environmental attitudes (Clewlow, 2016).

In view of the above arguments, the promotion of traditional car sharing is justified, but the social benefit seems to be potentially greater when using electric vehicles. Due to numerous obstacles in the proliferation of electric cars, car sharing based on this type of vehicles will be implemented gradually. The main importance should be attached to a different dimension of infrastructure - parking places and charging stations.

Analysts and experts predict that sharing, along with other sectors, will significantly determine people's activity in mobility and production of energy (Cooper \& Timmer, 2015). We can also assume that car sharing will affect the structure of the automotive industry, business models connected with new ways of usage, vehicle distribution and charging, urban mobility and pollutant emissions (Fournier et al., 2015).

Based on scientific research, car sharing, which can lead to eliminating up to ten private cars in place of one shared, to decreasing pollution and "releasing" a part of occupied urban areas, seems to be an important and desirable element of urban mobility. A literature review of the American car sharing customers suggests that heavy users give up (sell) their car (from 5 to $55 \%$ of users), and some (from 7 to $70 \%$ ) refrain from buying one (Shaheen et al., 2012). The results of research from the German market indicate that a vehicle used in city car sharing can replace even up to 20 individual cars and reduces the number of owned cars by $62 \%$ (Münzel, 2017). Based on the results of research in the Netherlands, it was confirmed that car sharing reduces car journeys by approx. $15-20 \%$ and the car ownership rate per household drops from 1.12 to 0.76 (Nijland \& van Meerkerk, 2017).

\subsection{Car Sharing as a Business Model of the Sustainable Mobility Ecosystem?}

As a rule, car sharing is a service in which different types of cars can be used: diesel, gasoline, hybrid, gas and electric, and so it is in practice. However, low availability of charging infrastructure makes electric vehicles less convenient and even in more advanced countries and markets, electric car sharing is very rare because combustion engine offers much more flexibility of use (Tchorek et al., 2018).

It seems that the introduction of car sharing, especially based on the electric vehicle fleet, will increase the use of various information and communication technologies and can significantly affect transport system efficiency in agglomerations and minimize related burdens (air pollution, noise, fewer accidents, etc.)

The electric vehicle use is easier to popularize through car fleets thanks to more efficient cost (use and maintenance) and charging infrastructure management. Car sharing is undoubtedly a fleet-based system, although it is specific in many respects. For example, the so-called free float model, which is most convenient for the consumer, may result in accidental dispersion of vehicles, requiring their relocation.

Electric car fleet operators seem to be more likely to overcome a major barrier to the popularization of electric vehicles among consumers, namely the price. Even with a still higher price of electric vehicles, the car sharing service does not have to be much more expensive since the cost of buying/hiring a vehicle is divided among more users and the vehicle operation is more optimal than in the case of many individual 
users. A lesser need to pass the higher cost of buying a car to a consumer of car sharing services may result from the opportunities offered by cheaper energy prices at night and energy use or resale to the power grid during the day. It can be expected that a considerable potential for stabilizing the power grid will be an effect of the use of electric fleet vehicles, also using renewable energy sources (Tchorek et al., 2018).

The charging infrastructure is a critical factor for the functioning of the electromobility market and an element of value creation for and by the customer. An electric vehicle uses ICT infrastructure and electrical charging infrastructure. The ICT infrastructure ensures G2V and V2G energy transfer, current information about available charging stations, bidirectional communication between the vehicle and the monitoring station. A necessary element of the infrastructure is a smart grid enabling communication between all actors in the energy sector. It fosters energy efficiency and integrates dispersed energy sources.

\subsection{Car Sharing Operators Market Research in Poland - How Far to the German Benchmark?}

Between January and April 2018, we conducted an on-line survey and in-depth interviews among Polish car sharing operators and collected data related to the market potential. Data referred to 2017. This allowed for defining sharing operator characteristics. What is interesting, sharing operators have very different origins.

In terms of the core business activity, traditional car rental is most similar to car sharing. Therefore, two biggest traditional car rental players- Traficar (present in 5 cities with the highest number of available cars - combustion engine) and PANEK CarSharing (hybrid engine) have entered the car sharing market. The second group of companies comprises IT firms - Keratronic and Enigma, which offer the software dedicated to mobility services. In 2018, a Warsaw-based retail energy operator (Innogy) tested the services of electric car sharing in cooperation with Keratronic. A technological (owned by energy distributor ENERGA) company - Enspiron - conducted a pilot project using car sharing in business-to-business relations within a stationary system in a very strict localization in Tricity. 4mobility (listed on the stock exchange) has also its own specificity and is an important operator which was involved deeply in cooperation with car producers - BMW and Hyundai. At the end of 2017, in Wroclaw, an electric car sharing service (Vozilla) was launched, accompanied by a unique formula of private-public partnership. The main motivation of the IT partner, namely ENIGMA (located in Warsaw), was to promote IT solutions offered by the company.

The biggest Polish car sharing company Traficar had more than 1100 cars. Generally, car sharing was available in five Polish cities (including Tricity) and the total number of cars was around 2000 . The number of registered users reached the level of 90000 . The total number of operators in Poland during the survey was seven companies.

While companies' diversification should be seen as a promising, a comparison to Germany (more than 160 operators are present in more than 600 cities, 2 million registered users) confirms the infancy stage of the market development in Poland (car sharing started to develop in Poland in 2017 and 30 years ago in Germany) - see Table 1.

The car sharing market in Germany is much more developed than in Poland. An average age of operator companies in every system in significantly bigger. Cooperative system companies have been operating on the market for an average of 13.3 years, roundtrip system companies for an average of 10.4 years, one-way system for an average of 4.8 years and peer to peer for an average of 5.7 years.

Similar to Poland, most German operators derive from car rental companies or car manufacturers. A difference is in the type of used systems. While Polish market is dominated by free-floating car sharing, in Germany the market is much more diversified.

What is very important (and what probably enabled many companies to operate on the German market), operators in Germany cooperate with local authorities and public transport companies much more often than the ones in Poland. Depending on a type of used system, the percentage of companies which are in a partnership with public entities vary from $24 \%$ (cooperative type) to even $100 \%$ (one-way system). Polish operators declared very small interest in cooperation from public institutions and it might be one of the main obstacles to car sharing market development. 
Table 1. Characteristics of car sharing business models in Germany

\begin{tabular}{|c|c|c|c|c|}
\hline Business model & Type 1 cooperatives & Type 2 B2C roundtrip & Type 3 B2C one-way & Type 4 P2P \\
\hline Number of firms & 51 & 43 & 4 & 3 \\
\hline Average age & 13.3 & 10.4 & 4.8 & 5.7 \\
\hline $\begin{array}{l}\text { Average number of cities } \\
\text { served }\end{array}$ & 1.2 & 7.2 & 3.5 & $\mathrm{n} / \mathrm{a}^{*}$ \\
\hline Average size of cities served & 39,966 & 229,823 & $1,669,684$ & $\mathrm{n} / \mathrm{a}$ \\
\hline \multicolumn{5}{|l|}{ Value proposition } \\
\hline Trip type & Roundtrip & $\begin{array}{l}\text { Roundtrip } \\
12 \% \text { roundtrip and OW } \\
\text { (mostly experiments) }\end{array}$ & One-way & Roundtrip \\
\hline Fleet ownership & \multicolumn{3}{|l|}{ Fleet owned by provider } & Cars owned privately \\
\hline Fleet variety & Varying car models (if \# of cars $>1$ ) & $91 \%$ varying models & $75 \%$ one-car model & Varying models \\
\hline \multicolumn{5}{|l|}{ Value network } \\
\hline \multirow[t]{2}{*}{ Owner background } & Non-incumbent & $\begin{array}{l}88 \% \text { non-incumbent } \\
12 \% \text { incumbent }\end{array}$ & $75 \%$ incumbent owner & Car sharing startups \\
\hline & car sharing startups & $\begin{array}{l}74 \% \text { car sharing startups } \\
4 \text { utility } \\
3 \text { car rental } \\
2 \text { car manufacturer } \\
1 \text { car dealer, } 1 \text { rail operator }\end{array}$ & $\begin{array}{l}1 \text { car manufacturer } \\
2 \text { car manufacturer/car } \\
\text { rental joint ventures } \\
1 \text { car sharing startup }\end{array}$ & All car sharing startups \\
\hline Partners & $\begin{array}{l}12 \% \text { public transit } \\
24 \% \text { city-related partners }{ }^{* *}\end{array}$ & $\begin{array}{l}42 \% \text { public transit } \\
40 \% \text { city-related partners } \\
19 \% \text { car-related partners }\end{array}$ & $\begin{array}{l}100 \% \text { public transit } \\
50 \% \text { city-related partners } \\
50 \% \text { car-related partners }\end{array}$ & 1 city-related partner \\
\hline \multicolumn{5}{|l|}{ Value capture } \\
\hline Profit & Not-for-profit & For-profit & & \\
\hline Fee structure & $\begin{array}{l}2 / 3 \text { registration fee } \\
78 \% \text { monthly fee } \\
\text { Hourly fee }\end{array}$ & $\begin{array}{l}64 \% \text { registration fee } \\
64 \% \text { monthly fee } \\
93 \% \text { hour fee }\end{array}$ & $\begin{array}{l}100 \% \text { registration fee } \\
100 \% \text { no monthly fee } \\
100 \% \text { minute fee }\end{array}$ & $\begin{array}{l}\text { No registration fee } \\
\text { No monthly fee } \\
\text { Hourly or part-day/day prices }\end{array}$ \\
\hline
\end{tabular}

$\mathrm{n} / \mathrm{a}^{*}$ - P2P carsharing is offered all over Germany, since a private car owner in any location can register his or her car on the platform. Therefore no precise data is collected on the number of cities where P2P carsharing is offered.

city-related partners $^{* *}$ - City-related partners include municipalities, local utilities, building associations.

car-related partners $^{* * *}$ - Car-related partners include car dealers, car leasing companies, car rental companies.

n/a - not available.

Source: Munzel et al. (2017). 


\section{Car Sharing Companies in Poland in 2017}

First car sharing companies started operating in Poland before 2017, but since the second quarter of 2017 we have been observing a rapid growth of the shared mobility market. At the end of 2017, there were almost 2000 vehicles used in car sharing systems in Poland. The biggest player on the market, Traficar, had a volume market share of $57.28 \%$ (1106 cars). Two operators took equal second place: Panek CarSharing and 4mobility used 300 cars each in their car sharing systems (see Table 2).

Most of the cars used by car sharing operators were powered by internal combustion engines. Electric cars represented $9.75 \%$ of all vehicles (159 out of 1631), hybrid cars $21.46 \%$ (350), internal combustion cars $68.79 \%$ (1122). 4mobility vehicles were not included in this calculation due to the lack of information (see Table 3).

Table 2. Number of vehicles in car sharing systems in Poland (end of 2017)

\begin{tabular}{|l|c|c|}
\hline \multicolumn{1}{|c|}{ Name of car sharing operator } & $\begin{array}{c}\text { Number of cars in car } \\
\text { sharing fleet }\end{array}$ & $\begin{array}{c}\text { Volume market share } \\
(\boldsymbol{\%})\end{array}$ \\
\hline Traficar & 1106 & 57.28 \\
\hline Panek CarSharing & 300 & 15.54 \\
\hline 4mobility & $300^{*}$ & 15.54 \\
\hline Enigma (Vozilla) & 150 & 7.77 \\
\hline Keratronik & 50 & 2.59 \\
\hline POL-MOT Auto S.A. (Omni) & 16 & 0.83 \\
\hline Enspirion & 9 & 0.47 \\
\hline Total & 1931 & \\
\hline
\end{tabular}

Data extracted from the operator's site: www.4mobility.pl not the survey. 4mobility refused to be surveyed during our research.

Source: Own calculation based on data collected through a questionnaire.

Table 3. Models of cars used by car sharing operators

\begin{tabular}{|l|l|l|l|}
\hline Name of operator & \multicolumn{1}{|c|}{ Drive type } & Models of used vehicles & $\begin{array}{c}\text { CITY/stationary/free- } \\
\text {-floating }\end{array}$ \\
\hline Traficar & $\begin{array}{l}\text { Internal combustion } \\
\text { engine }\end{array}$ & $\begin{array}{l}\text { Opel Corsa, Renault Clio, } \\
\text { Renault Kangoo }\end{array}$ & $\begin{array}{l}\text { Warszawa, Poznań, } \\
\text { Wrocław, Trójmiasto; } \\
\text { Free-floating }\end{array}$ \\
\hline Panek CarSharing & Hybrid & Toyota Yaris & Warszawa; Free-floating \\
\hline 4mobility* & $\begin{array}{l}\text { Internal combustion } \\
\text { engine, electric }\end{array}$ & $\begin{array}{l}\text { Hyundai i30, BMW 1, } \\
\text { BMW 3, MINI, BMW i3 }\end{array}$ & Warszawa; Free-floating \\
\hline Enigma (Vozilla) & Electric & Nissan Leaf, Nissan e-NV200 & Wrocław; Free-floating \\
\hline Keratronik & Hybrid, Electric & $\begin{array}{l}\text { Toyota Yaris, Renault Zoe, } \\
\text { Nissan Leaf, BMW i3 }\end{array}$ & Poznań; Free-floating \\
\hline $\begin{array}{l}\text { POL-MOT } \\
\text { Auto S.A. (Omni) }\end{array}$ & $\begin{array}{l}\text { Internal combustion } \\
\text { engine }\end{array}$ & $\begin{array}{l}\text { Skoda: Citigo, Fabia, Rapid, } \\
\text { Octavia }\end{array}$ & Warszawa; Stationary \\
\hline Enspirion & Electric & $\begin{array}{l}\text { Nissan Leaf, VW E-Golf, } \\
\text { Renault Zoe, VW E-Up }\end{array}$ & Gdańsk; Stationary \\
\hline
\end{tabular}

" Data extracted from the operator's site: www.4mobility.pl not the survey. 4mobility refused to be surveyed during our research.

Source: On-line research questionnaire and data extracted from an operator's site.

Wydział Zarządzania UW https://doi.org/10.7172/1733-9758.2018.29.5 
In 2017, the biggest number of car sharing vehicles was available for customers in Warsaw. The following table shows a full classification of car sharing vehicles available in particular Polish cities in 2017 (see Table 4).

Table 4. Number of car sharing vehicles available in particular Polish cities

\begin{tabular}{|l|c|}
\hline \multicolumn{1}{|c|}{ City } & Number of sharable cars in 2017 \\
\hline Warszawa & 916 \\
\hline Kraków & 306 \\
\hline Wrocław & 300 \\
\hline Tricity & 209 \\
\hline Poznań & 200 \\
\hline
\end{tabular}

* The table includes 4mobility vehicles.

Source: On-line research questionnaire and data extracted from an operator's site.

During our research at the beginning of 2018, four out of seven operators declared their plans to increase the number of cars in their fleets in the following year. The companies fulfilled their plans, making more than 1100 new cars available in car sharing systems.

\subsection{Users, Pricing and Public Transport Complementarity}

At the end of 2017, the total number of registered users in all car sharing systems in Poland was 91 849. That gives an average of 51.31 registered users per one car sharing vehicle (the calculation does not include 4mobility users).

Trips in free-floating systems were much shorter, but also more frequent. An average number of trips in a week per one vehicle was equal to 15.5 , an average trip took 16 minutes and was 6.5 kilometres long. Each vehicle in stationary systems was rented on average three times a week, an average journey took 12.5 hours and was 72.5 kilometres long (compare Table 5).
In comparison to the mature car sharing market in Germany (first system started operating in $1988^{2}$ ), these numbers do not look impressive. Data for the same period of time (1 Jan. 20183) shows that at the end of 2017 there were 2110000 registered users in Germany and 17950 car sharing vehicles, of which 10050 were used in stationary systems and 7900 in free-floating systems.

Payment systems in Poland are different from the ones encountered in most European countries. In Poland, operators charge for both the time spent in a car (minutes) and the distance covered (kilometres) - compare Table 6.

Table 6. Average prices of car sharing services in Poland and Germany

\begin{tabular}{|l|l|}
\hline \multicolumn{2}{|c|}{ Poland } \\
\hline $\begin{array}{l}\text { Average price per } \\
\text { minute of driving }\end{array}$ & PLN $0.54=$ EUR 0.13* \\
\hline $\begin{array}{l}\text { Average price per } \\
\text { kilometre }\end{array}$ & PLN $0.64=$ EUR 0.15 \\
\hline $\begin{array}{l}\text { Average price per } \\
\text { minute of parking }\end{array}$ & PLN $0.17=$ EUR 0.04 \\
\hline \multicolumn{2}{|c|}{ Germany } \\
\hline $\begin{array}{l}\text { Price per minute of } \\
\text { driving in Germany } \\
\text { (as exemplified by } \\
\text { the market leader } \\
\text { Car2go) }\end{array}$ & EUR 0.26-0.34 \\
\hline
\end{tabular}

* EUR $1=$ PLN 4.3105, data from the National Bank of Poland as at 18 Aug. 2018.

Source: Own calculation based on data collected through a questionnaire. Data extracted from Car2go website.

The tariff per minute differs also when the car is parked during our rental time (stop over) and when we are driving. The average price per minute of driving is PLN 0.54,

Table 5. Use of vehicles in free-floating and stationary systems at the end of 2017

\begin{tabular}{|l|c|c|c|}
\hline & $\begin{array}{c}\text { Average number of trips } \\
\text { in a week per vehicle }\end{array}$ & $\begin{array}{c}\text { Average time } \\
\text { of one trip }\end{array}$ & $\begin{array}{c}\text { Average distance } \\
\text { of one trip }\end{array}$ \\
\hline Stationary car sharing & 3 & 12.5 hours & $72.5 \mathrm{~km}$ \\
\hline Free-floating car sharing & 15.5 & 16 minutes & $6.5 \mathrm{~km}$ \\
\hline
\end{tabular}

Four companies were included in the calculation. Stationary systems from Enspirion and POL-MOT Auto S.A., free-floating systems from Enigma and Panek CarSharing.

Source: Own calculation based on data collected through a questionnaire. 
the average price per minute of parking stands at PLN 0.17, and the average price per kilometre covered is PLN 0.64. In other European countries, for example Germany, most companies charge their customers only for the time spent in a car (minutes). For the sake of comparison, prices in Germany range from EUR 0.26 to EUR 0.34 per minute of rent (in the case of the biggest car sharing company on the market Car2go). The operator also charges an extra EUR 0.29 per every additional kilometre over $200 \mathrm{~km}^{4}$

\subsection{Target Group}

Who is in the target group of car sharing operators and to whom do operators offer their services in Poland? Almost all companies chose people who are young and who do not own a private car as the main target group of their services (five out of six operators). Three out of six operators marked also people who use public transport (for whom car sharing could be a complementary mobility service). None of the respondents marked customers who expect comfort and prestige. However, there are companies which offer their services to customers who expect prestige brands and who are ready to pay more for such a service. On the Polish market, 4mobility offers their BMW and MINI vehicles to this group of customers.

In the opinion of the respondents, car sharing services are complementary to pub- lic transport. All operators agreed with this statement. Interestingly, half of the operators consider their services as competition to Uber and taxis, and the other half think exactly the opposite.

\subsection{Programmes of Permanent Cooperation With Clients and Other Stakeholders}

Beside offering services to individual customers, the operators permanently cooperate with institutional clients. Five out of six companies engage in lasting cooperation with institutional clients, including for instance developers, real estate management companies or insurance companies. In the last case, car sharing operators offer for example access to car sharing vehicles instead of replacement cars in the case of insurance companies.

Table 7. Programmes of cooperation between car sharing operators and other stakeholders

\begin{tabular}{|l|l|}
\hline $\begin{array}{l}\text { Institutional } \\
\text { customers }\end{array}$ & $\begin{array}{l}5 \text { out of } 6 \text { car sharing } \\
\text { operators }\end{array}$ \\
\hline $\begin{array}{l}\text { Developers and real } \\
\text { estate management }\end{array}$ & $\begin{array}{l}4 \text { out of } 6 \text { car sharing } \\
\text { operators }\end{array}$ \\
\hline Insurance companies & $\begin{array}{l}3 \text { out of } 6 \text { car sharing } \\
\text { operators }\end{array}$ \\
\hline Parking operators & $\begin{array}{l}\text { 1 out of } 6 \text { car sharing } \\
\text { operators }\end{array}$ \\
\hline
\end{tabular}

Source: On-line research questionnaire.

Figure 6. Target groups to which operators offer their services

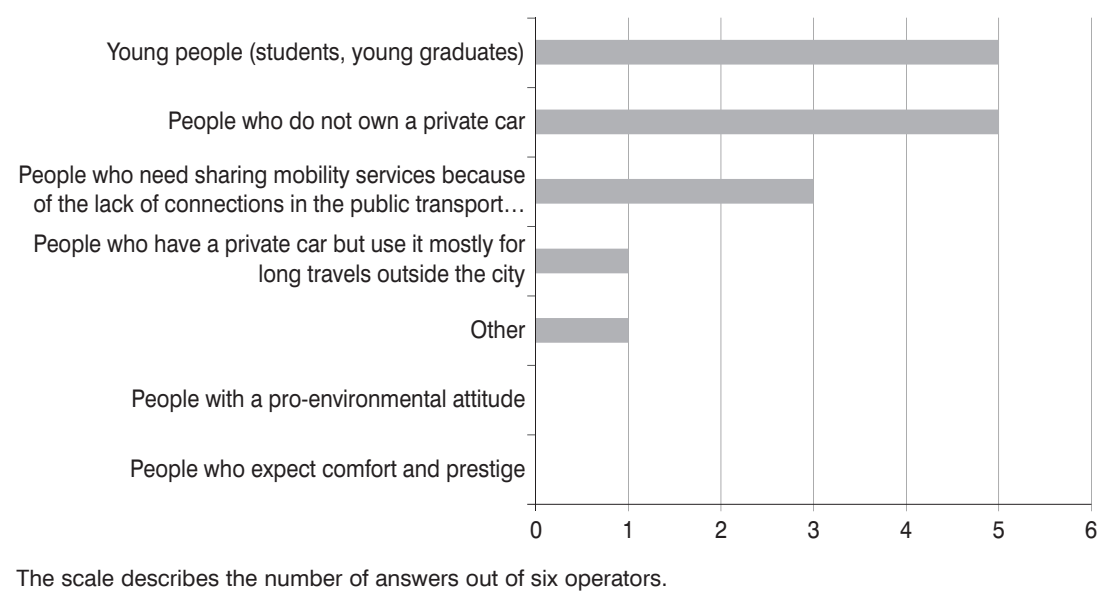

Source: On-line research questionnaire.

Wydział Zarządzania UW https://doi.org/10.7172/1733-9758.2018.29.5 


\section{Challenges to the Growth of Car Sharing in Poland}

What are the biggest obstacles to the growth of car sharing in Poland in the opinion of operators? The lack of awareness of the existence of such services among clients and the absence of coherent city policies regarding the promotion of sharing mobility. Both answers were selected by four out of six operators. Half of the respondents chose also the answer that city policies regarding the use of private cars (fees for parking, low-emission zones) are too liberal. Answers to the question about the biggest obstacle to the growth of the respondent's company were quite predictable. First and foremost, the operators chose the lack of adequate legal regulations. The new type of service on the Polish mobility market calls for implementing dedicated regulations. That is what operators expect to change in the near future. The second most frequently selected response concerned administrative barriers, and the third one - financial constraints.

Car sharing is not the only form of sharing mobility whose popularity has been growing recently. All the operators indicated that scooter sharing companies, Uber and taxis also operate in the cities where car sharing is available. Bike sharing was indicated by five out of six companies. The sharing mobility market in Poland will probably grow rapidly in the next years. All the operators were positively disposed toward the prospects for the development of car sharing in Poland. Five out of six companies assessed these prospects as good, one company as very good.

\subsection{Electric Vehicles in the Car Sharing Fleet, the Optimal Electric Car}

Four out of six operators provided a positive answer to the question whether they were planning to add electric vehicles to their fleet in the near future. What is an optimal electric car for car sharing? All the operators are of the same opinion: vehicles should have seats for four passengers and be adapted to short and frequent journeys. Meanwhile, many companies around the world are introducing small electric twoseater cars, which is a rational approach keeping in mind the main aims of car sharing: trying to decrease the traffic in cities and making them less polluted (and energy efficient). There certainly are situations where bigger cars in car sharing systems have their advantages, and probably the best solution is to diversify the fleet, but for the time being the interviewed operators in Poland do not consider adding small cars to their offer. What is the optimal/sufficient range of an electric car sharing vehicle? The most popular answer was 200-300 kilometres (four out of six operators), although some of the companies are ready to use electric cars with a smaller range under certain conditions (vehicles would have to be equipped with a battery swapping system or clients would have to take responsibility for charging the vehicles).

Figure 7. Optimal range of an EV in a car sharing system

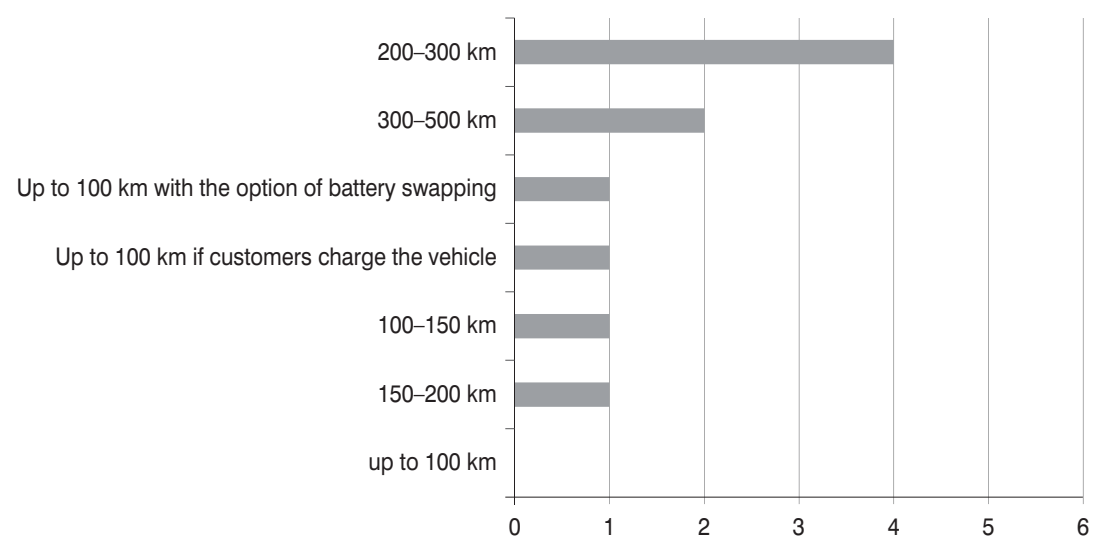

Source: On-line research questionnaire. 


\subsection{The Charging Infrastructure Is the} Main Problem for Electric Vehicles

There are a few barriers to using electric cars in sharing systems today as electric vehicles have just started gaining on popularity (the trend is more and more visible). As the most significant barriers, the car sharing operators in Poland chose the lack of charging infrastructure, high prices of vehicles and their small range. None of the companies is afraid of little interest in electric cars among its customers, or of a decline in the value of the cars (due to the ageing of the battery, the cost of which represents a substantial portion of the cost of the whole car) These obstacles could be overcome by local authorities. The operators are of the opinion that in order to help popularize shared electric vehicles, it would be best to develop fast charging infrastructure and provide dedicated conveniences for using such cars in the city (for example dedicated parking spaces, free-of-charge parking in city centres, access to bus lanes or low-emission zones). All the companies (six out of six) share both these opinions. The second most popular answer was gaining access from local authorities to parking with charging infrastructure at night, for instance Park\&Ride ones (parking located at the city border, often acting as a transport hub, which allows switching from cars to other means of transport - underground, trams, buses).

Concerns about using electric vehicles in car sharing systems and expectations of support from the authorities do not mean that there is currently no cooperation between these entities. Some of the operators declared gaining access to free parking spots, collaborative promotion of shared mobility or development of charging infrastructure for EVs. On the other hand, one of the operators declared no cooperation at all, or even aversion of local authorities to any form of big ventures. The operators mentioned the inclusion of car sharing in public transport as a form of cooperation which could increase the promotion and exploitation of car sharing services in the future.

\section{Changes on the Car Sharing Market in 2019 - A Short Update (May 2019)}

Since the beginning of 2018 (date of collected data for research purposes), the car sharing market in Poland has been growing as predicted. The biggest companies have added new cars to their fleets and started offering their services in subsequent cities. We have seen new companies enter the market as well.

In May 2019, the biggest Polish car sharing operator Traficar pursued its business in seven cities (Kraków, Warszawa, Wrocław, Poznań, Bydgoszcz, Lublin, Lódź) and two agglomerations (Tricity, Silesia). In January 2019, the company had 1705 cars in its fleet, and in March 2019, the number of registered users reached $200000 .^{5}$ From August 2018 to January 2019, Traficar tested also the electric Renault Zoe.

In May 2019, Panek CarSharing has a fleet of 1112 cars (Toyota Yaris, Toyota Corolla, 10 two-seat electric Smarts and one vintage Polonez Caro). The company operates in Warsaw and Lublin.

4mobility extended its business to cover Poznań and, besides BMW and Hyundai, now also offers a few Audi models. 6 Two companies included in the 2018 research have discontinued their operations. After the project's trial period, Omni car sharing (POL-MOT Auto S.A.) and Enspirion decided to leave the market.

In April 2019, the Polish energy company PGE Polska Grupa Energetyczna S.A bought $82 \%$ of 4mobility shares and announced a plan to change the fleet to an electric one. Earlier in 2018, PGE started its own experimental electric car sharing platform in Siedlce.

As predicted, the energy sector is interested in the shared mobility market. Besides PGE, two other big companies have started their car sharing platforms. Tauron Polska Energia operates in Katowice, and Innogy Polska S.A. has set up the company InnogyGO!, which has the biggest electric car sharing fleet in Poland and the third biggest in Europe (500 electric BMWs i3) ${ }^{7}$.

Other companies have entered the market as well, for example: EasyShare with the hybrid Toyota Yaris in Poznań and Łódź, Click2go, which is the fourth company operating in Poznań (and uses hybrid Toyota Yaris as well), GoGet operating in Wroctaw and MiiMove operating in Tricity.

Since the end of 2017, the Polish car sharing market has been growing rapidly. In May 2019, two biggest companies (Traficar and Panek CarSharing) have more 
cars in their fleet (2817) than all the companies on the market in 2017 (1931). The most significant trend of 2019 is offering low-emission vehicles, and it will probably continue in the years to come.

\section{Conclusions}

Our study was dedicated to car sharing operators' and cities' attitude to shared mobility and it was the first research in such a scale conducted in Poland. For this reason, the data is unique.

Results of our research indicate that although the Polish car sharing market is relatively small compared to Germany, its perspectives are very favourable. This is evidenced by the rapidly growing number of operators and the car fleet. This is obviously a feature of a young market, but a very fast growth rate and susceptibility to new technological solutions and enablers (i.e. electric cars) show the real potential of the Polish market. In the markets of emerging countries, changes take place much faster and it is easy to omit transitional stages. Therefore, there are already operators in Poland focused only on electric vehicles. However, as shown by the results of our research, all respondents are interested in the exchange (as least some part) of fleets to electric cars.

From the car sharing operators' perspective, we observed huge interest in offering car sharing services and dynamic changes in the market. What is also interesting, the car sharing service is becoming popular among Polish customers and more than 90000 users were registered at the end of 2017. The main challenge for the companies' development is still the lack of customer awareness of car sharing services availability and the lack of dedicated parking slots.

The conclusions of the car sharing operators survey are confirmed and reinforced by the city survey results. From the cities perspective, local governments recognize the need for innovative solutions matching the Smart City concept including shared mobility. Despite the identification of car sharing as a potential source of development, public transport or city bicycles are the main active steps taken. Such approach is good and desirable, because public transport is one of the main areas determining citizens' quality of life, but the problem is that cities develop public transport in a way which still does not take into account chances and opportunities given by shared mobility.

According to our view, the key success factors on the car sharing market and in the implementation of the Smart City concept will be the skilful cooperation of car sharing operators and local authorities, which should be placed in strategies of both actors. For example, advanced forms of cooperation between operators and cities are needed in order to ensure complementarity of public transport and car sharing. We also concluded that it is reasonable to pay much more attention to the availability of dedicated parking slots.

\section{Endnotes}

1 We are very grateful to the Electromobility Poland company for the support, help and comments during our research survey. We would also like to thank the Association of Polish Cities (Związek Miast Polskich) and representatives of car sharing companies and representatives of local authorities for their participation in the survey and for support.

2 www.carsharing.de/1988-werden-deutschlandprofessionell-autos-geteilt-0.

3 www.carsharing.de/presse/fotos/zahlen-daten/ carsharing-deutschland-fahrberechtigte-fahrzeuge- 0 .

4 www.car2go.com/DE/en/\#156129.

5 www.media.traficar.pl/53276-traficar-w-liczbach-infografika, access on 25.05.2019.

6 www.4mobility.pl/\#nasze-auta, access on 17.08.2018.

7 www.money.pl/gielda/innogy-polska-uruchamiaw-warszawie-elektryczny-car-sharing-innogy-go6366005592197249a.html, access on 25.05.2019.

\section{References}

Belk, R. (2014). You are what you can access: Sharing and collaborative consumption online. Journal of Business Research, 67(8), 1595-1600.

Caragliu, A., Del Bo, Ch., \& Nijkamp, P. (2011). Smart cities in Europe. Journal of Urban Technology, 18(2), 65-82.

Churchill Jr, G.A. (1979). A paradigm for developing better measures of marketing constructs. Journal of Marketing Research, 64-73.

Clarysse, B., Wright, M., Bruneel, J., \& Mahajan, A. (2014). Creating value in ecosystems: Crossing the chasm between knowledge and business ecosystems. Research Policy, 43(7), 1164-1176. 
Clewlow, R. (2016). Car sharing and sustainable travel behavior: Results from the San Francisco Bay Area. Transport Policy, 51, 158-164.

Corsaro, D. (2014). The emergent role of value representation in managing business relationships Industrial Marketing Management, 43(6), 985-995.

Dharmakeerthi, C.H., Mithulananthan, N., \& Saha, T.K. (2011). Overview of the impacts of plug-in electric vehicles on the power grid. 2011 IEEE PES Innovative Smart Grid Technologies. Australia: Perth, WA

Fitzgerald, G., \& Nelder, C. (2016). EVGO fleet and tariff analysis. Rocky Mountain Institute.

Glaeser, E.L., \& Berry, C.R. (2006). Why are smart places getting smarter? (Taubman Center Policy Brief 2006-2). Cambridge, MA: Taubman Center.

Heinrichs, H. (2013). Sharing economy: A potential new pathway to sustainability. GAIA - Ecological Perspectives for Science and Society, 22(4), 228-231.

Hamari, J., Sjöklint, M., \& Ukkonen, A. (2016) The sharing economy: Why people participate in collaborative consumption. Journal of the Association for Information Science and Technology, 67(9), 2047-2059.

Katzev, R. (2003). Car sharing: A new approach to urban transportation problems. Analyses of Social Issues and Public Policy, 3(1), 65-86.

Langbroek, J.H., Franklin, J.P., \& Susilo, Y. (2017). Changing towards electric vehicle use in Greater Stockholm. European Journal of Transport and Infrastructure Research, 17(3), 306-329.

Lan, J., Ma, Y., Zhu, D., Mangalagiu, D., \& Thornton, T.F. (2017). Enabling value co-creation in the sharing economy: The case of Mobike. Sustainability, 9, 1504

Liu, Q., Fang, H., Wang, J., \& Yan, S. (2015). The impact of electric vehicle charging on the grid. International Conference on Applied Science and Engineering Innovation (ASEI 2015), Atlantis Press.

Mu, Y., Wu, J., Jenkins, N., Jia, H., \& Wang, C. (2014). A spatial-temporal model for grid impact analysis of plug-in electric vehicles. Applied Energy, $114,456-465$

Munzel, K., Boon, W., Frenken, K., \& Vaskelainen, T. (2017). Car sharing business models in Germany: Characteristics, success and future prospects. Information Systems and e-Business Management, 16(2), 271-291.
Nijland, H., \& van Meerkerk, J. (2017). Mobility and environmental impacts of car sharing in the Netherlands. Environmental Innovation and Societal Transitions, 23, 84-91.

Pollak, R.A. (1970). Habit formation and dynamic demand functions. Journal of Political Economy, 78(4/1), 745-763.

Ranjar, K., \& Read, S. (2014). Value co-creation: Concept and measurement. Journal of the Academy of Marketing Science, 44(3), 290-315.

Resolution No. 16 of the Council of Ministers of 5 February 2013 concerning the adoption of the Long-Term National Development Strategy. Poland 2030. The third wave of modernity. Monitor Polski 2013, 121.

Roller, L.H., \& Waverman, L. (2001). Telecommunications infrastructure and economic development: A simultaneous approach. American Economic Review, 91(4), 909-923.

Salisbury, M., \& Toor, W. (2016). How leading utilities are embracing electric vehicles. Southwest Energy Efficiency Project.

Shaheen, S., Mallery, M., \& Kingsley, K. (2012). Personal vehicle sharing services in North America. Research in Transportation Business and Management, 3, 71-81.

Shapiro, J.M. (2006). Smart cities: Quality of life, productivity and the growth effects of human capital. Review of Economics and Statistics, 88(2), 324-335.

Smith, J., \& Colgate, M. (2007). Customer value creation: A practical framework. Journal of Marketing Theory and Practice, 15(1), 7-23.

Sunyer, J. (2001). Urban air pollution and chronic obstructive pulmonary disease: A review. European Respiratory Journal, 17, 1024-1033.

Tchorek, G., Allen, A., Dziewanowska, K., Geodecki, T., Kozioł, W., Pękalska, M., Wójtowicz, S. (2018). Electric car sharing as an interdisciplinary field of experiments in different scientific approaches. Submitted to The Archives of Automotive Engineering.

Wang, C., \& Zhang, P. (2012). The evolution of social commerce: The people, management, technology, and information dimensions. Communications of the Association for Information Systems, 31, Article 5.

Yi, Y., \& Gong, T. (2013). Customer value co-creation behavior: Scale development and validation. Journal of Business Research, 66(9), 1279-1284. 